\title{
Farklı Mıknatıs Yapıları ve Farklı Mıknatıs Malzemeleri Kullanımının Küresel Motorun Tasarımına Etkisi
}

\author{
Umut Yusuf Gündoğar ${ }^{1 *}$, Sibel Zorlu Partal ${ }^{2}$, \\ ${ }^{1}$ Yıldız Teknik Üniversitesi, Elektrik-Elektronik Fakültesi, Elektrik Mühendisliği Bölümü, İstanbul, Türkiye (ORCID: 0000-0002-5245-275X) \\ 2 Yıldız Teknik Üniversitesi, Elektrik-Elektronik Fakültesi, Elektrik Mühendisliği Bölümü, İstanbul, Türkiye (ORCID: 0000-0003-1309-2090)
}

(İlk Geliş Tarihi 17 Temmuz 2020 ve Kabul Tarihi 31 Ağustos 2020)

(DOI: 10.31590/ejosat.770998)

\begin{abstract}
ATIF/REFERENCE: Gündoğar, U. Y. \& Zorlu Partal, S. (2020). Farklı Mıknatıs Yapıları ve Farklı Mıknatıs Malzemeleri Kullanımının
\end{abstract} Küresel Motorun Tasarımına Etkisi. Avrupa Bilim ve Teknoloji Dergisi, (19), 946-959.

\section{$\ddot{O} \mathbf{z}$}

Günümüzde teknolojideki gelişmelere paralel olarak, robotik sistemlerde, tıp alanında, otomotiv sektöründe ve endüstriyel uygulamalarda çok serbestlik dereceli hareket yapabilen motorlara ihtiyaç giderek artmaktadır. Bu sebeple bu çalışmada, çok eksenli hareket kabiliyetine sahip bir sabit mıknatıslı küresel motor tasarımı yapılmış ve ANSYS Maxwell yazılımıyla sonlu elemanlar yöntemiyle (SEY) elektromanyetik analizleri gerçekleştirilmiştir. Analizlerde, motorun rotorunda yer alan farklı mıknatıs türleri ve mıknatıs yapılarının yanında, stator ve rotor nüvelerindeki farklı laminasyon türleri de dikkate alınarak motor tasarımları yapılmıştır. Mıknatıs olarak NdFe30, NdFe35, SmCo28 malzemeleri; mıknatıs yapısı olarak gömülü düz mıknatıs, gömülü V-tipi mıknatıs, yüzey mıknatıs; stator ve rotor yapılarındaki laminasyonlar için de steel_1008, M43_24G, JFE_Steel_50JNE300 malzemeleri kullanılarak oluşturulan her bir model için ayrı ayrı elektromanyetik analizler gerçekleştirilmiş̧tir. Her bir tasarım için manyetik akı yoğunluğu dağılımının manyetik doyum problemi incelenmiş, moment ve kuvvet değerleri hesaplanmış ve sonuçlar karşılaştırmalı olarak verilmişsir.

\section{The Effect of Using Different Magnet Structures and Different Magnet Materials on the Design of the Spherical Motor}

\begin{abstract}
Today, with the advances in technology, the need for motors capable of multi-degree of freedom in robotic systems, medicine, automotive industry and industrial applications is increasing. For this reason, in this study, a permanent magnet spherical motor design with multi-axis motion ability has been designed and electromagnetic analysis has been done with ANSYS Maxwell software using the finite element method. In the analysis, motor designs were made by considering different types of magnets in the rotor and different lamination types in the stator and rotor cores with different magnet structures. Electromagnetic analyzes were performed for each model created using steel_1008, M43_24G, JFE_Steel_50JNE300 materials in stator and rotor structures and NdFe30, NdFe35, SmCo28 materials as magnets with embedded straigt magnet, embedded V-type magnet, surface magnet structures.For each design, magnetic saturation problem of magnetic flux density distribution is examined, moment and force values are calculated and results are given comparatively.
\end{abstract}

Keywords: Design of Electrical Machines, Spherical Motor, Electromagnetic Analysis, Magnet, ANSYS Maxwell.

\footnotetext{
* Sorumlu Yazar: Yıldız Teknik Üniversitesi, Elektrik-Elektronik Fakültesi, Elektrik Mühendisliği Bölümü, İstanbul, Türkiye, ORCID: 0000-00025245-275X, umutgundogar@hotmail.com.tr
} 


\section{Giriş}

Teknolojinin zaman içinde hızlı ve sürekli gelişimi birçok alanda olduğu gibi robotik uygulamalarda da farklı ihtiyaçların ortaya çıkmasına ve bunlarla ilgili çözümler üretilmesine imkan sağlamıştır. Robotik uygulamalarda eksenel hareketler, bu uygulamaların çok yönlü sistemleri içinde barındırması ve hassas hareket kabiliyeti ile çalışmalar yapabilmeleri açısından oldukça önemli bir yere sahiptir. Çok yönlü hareketli sistemlerinde genellikle her bir eksen veya yön için farklı bir motor kullanmak gerekirken, çok yönlü hareket kabiliyetine sahip küresel motorların bu sistemlerde kullanılmasıyla aynı işlem tek bir küresel motorla gerçekleştirilebilmektedir. Böylece hem sistemi oluşturan eleman sayısı ve sistemin maliyeti azalmakta, hem de tek bir küresel motorla tüm bu işlevler yerine getirilerek kontrol kolaylığı sağlanabilmektedir. Bu sebeple bu çalışmada, küresel motorun daha büyük açılarda eksenel hareket kabiliyetine sahip olmasını sağlanacak özel bir tasarımın gerçekleştirilmesi ve moment, kuvvet parametreleri üzerinde çalışmalar yapılarak, endüstriyel uygulamalarda kullanılması hedeflenmiştir.

Küresel motorlar üzerine tasarım, çalışma performansları, yapıları gibi birçok bakımdan farklı çalışmalar yapılmıştır. Yapılan çalışmalar motorda kullanılan malzemelerin ve motorun tasarımının, motorun performansına etkisinin önemli olduğu göstermiştir. Küresel motorların geçmişi 1900'lü yıllara uzanmaktadır. İlk küresel motor üzerine çalışmalar Manchester Üniversitesi'nde tarafından yapılmıştır. Çalışmalarda statoru küre şeklinde olan indüksiyon motoru tasarlammıştır. Tasarlanan motorun çalışma prensibi hareketli statorda yer alan sacların yerleşim düzenin farklılığına dayanmaktadır (Williams, Laithwaite ve Piggot, 1956); (Williams, Laithwaite, Eastham, 1959); (Laithwaite, 1960). Küresel motor üzerine yapılan bu ilk çalışmalar, başka araştırmacıların tasarım ve kontrol üzerine çalışmalarıyla günümüze kadar devam etmiştir. Bir başka çalışmada üç eksenli hareket kabiliyetine sahip sabit mıknatısl $360^{\circ}$ dönme hareketinin yanında, $45^{\circ}$ doğrusal hareket yeteneğine sahip bir küresel motor tasarlanmıştır (Öner, 2004). Başka bir çalışmada rotorunun sabit mıknatıslardan oluştuğu ve statorunun küresel sargılardan oluştuğu eksenel olarak $37^{\circ}$ açısal hareket kabiliyetine sahip olan bir küresel motor geliştirilmiştir (Takahara, Hirata, Niguchi, Nishiura ve Sakaidani, 2017). Yapılan başka bir çalışmada rotoru üzerinde 8 adet sabit mıknatıs bulunan ve 20 adet küresel sargısı olan stator yapısından oluşan bir küresel motor geliştirilmiştir (Li, Li ve Li, 2017). Bir diğer küresel motor çalışmasında ise çok serbestlik dereceli bir küresel motor çalışması gerçekleştirilmiştir. Küresel motorun statorunda yer alan 3 katlı sargılardan ortadaki sargılar motorun dönüşünü sağlarken, alt ve üst sargılar eksenel hareket için enerjilendirilerek küresel motorun hareketi gerçekleştirilmiştir (Li, Bai, Chen ve Liu, 2017). Sabit mıkatıslı küresel motorun geri yayılım yapay sinir ağları yöntemiyle modellenmesi konusunda küresel motorun çalışmasını gerçekleştirmişlerdir (Zhou, Li, Zhou, Ju, Ma ve Cao, 2017). Rotorunda 8 adet sabit mıknatıs olan ve statoru 16 küresel sargıdan oluşan sabit mıknatıslı bir küresel motorun, $37^{\circ}$ eksenel hareket kabiliyetine sahip olacağı şekilde çalışma gerçekleştirilmiştir (El-Khalafawy ve El-Amary, 2017). Halbach dizisinde sabit mıknatıs yapısından ve üç katlı stator bloğundaki sargılardan oluşan küresel motoru, SEY kullanılarak analizlerini gerçekleştirdikten sonra prototipini oluşturulmuştur (Li ve Li, 2018). Bir diğer çalışmada sabit mıknatıslardan oluşan küresel motorun rotorunun dönüş hareketini blok yapısında stator oluşturarak sağlanmıştır. Küresel motorun SEY kullanılarak analizleri gerçekleştirdikten sonra hareket kabiliyetlerini ve moment değerleri elde edilmiştir (Ahmadi, Moghani ve Mirsalim, 2018).

Rotoru demir yapıdan ve dışı bakır yapıdan oluşan, statoru da asenkron makinalardaki çalışma prensibine benzer çalışan bir indüksiyon küresel motor tasarlanmış ve analizleri gerçekleştirilmiştir (Yan, Duan, Zhang, Qiao ve Gerada, 2018). Moment değerlerini stator sargılarına uygulanan enerjilendirmeye göre $0.13 \mathrm{Nm}$ değerlerinde elde etmişlerdir (Yan, Duan, Zhang, Qiao ve Gerada, 2018). Bir başka çalışmada sabit mıknatıslı küresel rotorun etrafına eksenel ve rotasyonel hareketleri sağlaması için sargılar yerleştirerek farklı bir motor tasarımı yapılmıştır (Cho, Lim, Oh, Jeong, Kang ve Lee, 2018). Japonya Osaka Üniversitesi'nde yapılan bir çalışmada rotoru sabit mıknatıslardan oluşan ve sator sargı yapılarının nüve bloklarından olacak şekilde bir küresel motor tasarlanmıştır (Li, Chen, Yue ve Zhang, 2018). MEMS atalet ölçüm sensörü kullanılara küresel motorların algılama performansını iyileştirmek için sabit mıknatıslı bir küresel motor tasarlanmıştır (Rong, Wang, Lu, Li, Lu ve Xu, 2018). Yine sabit mıknatıslı bir rotora sahip küresel motor, nüve üzerinde sargı yapıları bulunan stator ile enerjilendirilerek, eksenel ve rotasyonel hareket kabiliyetine sahip küresel bir motor üzerine çalışmalar yapılmıştır (Li, Chen ve Wang, 2019).

Bu çalışmada ise, sabit mıknatıslı bir küresel motorun tasarımı gerçekleştirilmiş ve ANSYS Maxwell yazılımı kullanılarak, SEY kullanılarak manyetik analizleri yapılmıştır. Küresel motorun rotorunda bulunan mıknatısların yerleşim şekilleri olarak gömülü düz, gömülü V-tipi ve yüzey şekli referans alınarak, mıknatıs malzeme olarak NdFe30, NdFe35, SmCo28 malzemeleri kullanılarak ve stator ile rotor yapılarında steel_1008, M43_24G, JFE_Steel_50JNE300 çelik malzemeleri kullanılarak 216 adet elektromanyetik analiz gerçekleştirilmiştir. Elektromanyetik analizlerle motorun hareketlerine bağlı olarak manyetik akı yoğunluğu dağılımları, moment ve kuvvet değerleri elde edilmiştir.

\section{Küresel Motorun Tasarımı ve Yapısı}

Bu çalışmada tasarlanan küresel motorda üç adet aynı yapıda stator bulunmaktadır. Her bir stator yapısında altı adet olmak üzere, küresel motorun statorunda toplamda on sekiz adet sargı bulunmaktadır. Stator blokları $19 \mathrm{~mm}$ mesafe aralığında tasarlanmıştır. Böylece kutup ayaklarına sarılacak sargılara yer bırakılmıştır. Sargılar 90 sarım sayısından ve 0,81 mm çapındaki bakır iletkenlerden oluşmaktadır. Statorun sargılarına bakır malzeme tanımlanmıştır. ANSYS Maxwell ve ANSYS SpaceClaim Direct Modeler yazılımları kullanılarak oluşturulan stator nüve yapısı ve bu nüveye sargıların yerleştirilmiş hali, sırasıyla Şekil 1 ve Şekil 2'de gösterilmiştir. 


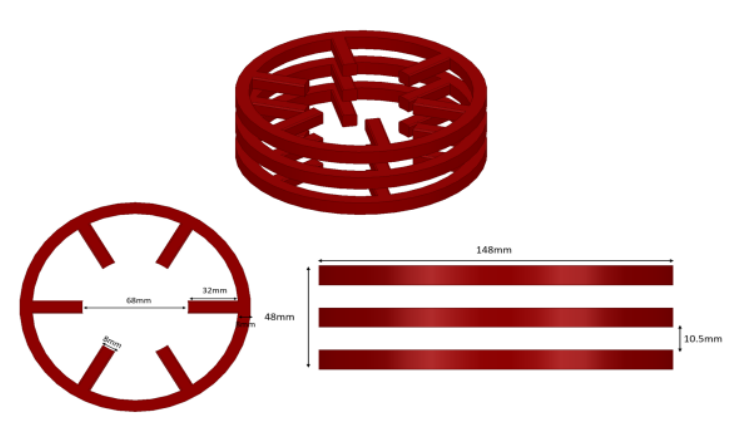

Şekil 1. Küresel motorun stator yapısı

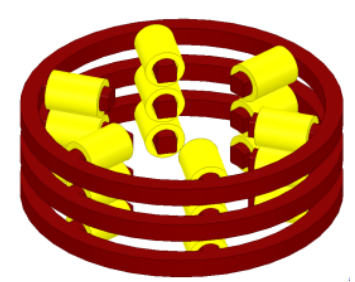

Şekil 2. Stator sargıları yerleştirilmiş küresel motor

Küresel motorun rotoru dört kutuplu bir yapıya sahiptir. Rotorda yer alan sabit mıknatıslar birbirleriyle $90^{\circ}$ açı yapacak şekilde ve 2 adet $\mathrm{N}$ kutbu ve 2 adet $\mathrm{S}$ kutbu olacak şekilde modellenmiştir. Böylece sargılardan geçirilecek akımların oluşturacağı manyetik alan kuvvetine göre rotor hareketi sağlanmış olacaktır. Ayrıca küresel motorun hareket eksenine bağlı olarak yön tayinini yapabilmek için, 40 mm'lik kısmı rotorun içinde kalacak şekilde, 60 mm uzunluğunda bir motor mili modellenmiştir. Mil, çelik malzemeden yapılmıştır. Tasarlanan küresel motorun rotor yapısının gömülü düz mıknatıs, gömülü V-tipi mıknatıs ve yüzey mıknatıs olarak modellenmiştir ve modeller sırasıyla Şekil 3'te gösterilmiştir.
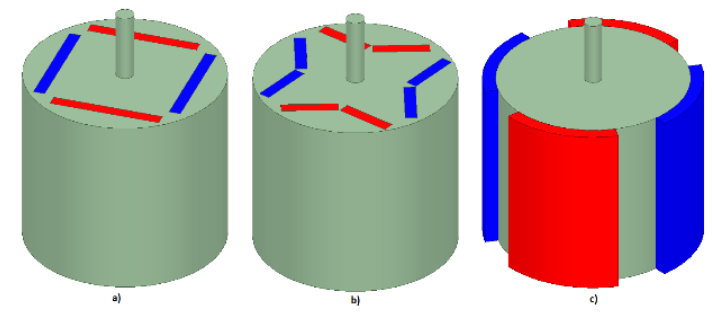

Şekil 3. Küresel motorun rotorunun genel yapısı a) Gömülü düz mıknatıslı rotor yapısl, b) Gömülü V-tipi mıknatıslı rotor yapısl, c) Yüzey mıknatıslı rotor yapısı

Küresel motorun tüm bileşenlerinin modellemesi ANSYS Maxwell yazılımı ile gerçekleştirilmiştir (ANSYS Maxwell Online Help, 2020); (ANSYS Maxwell 2020R1, 2020). Statoru, rotoru ve sargıları ayrı ayrı modellenen küresel motorun, tüm parçalarının birleştirildiği genel yapısı Şekil 4'te gösterilmiştir.

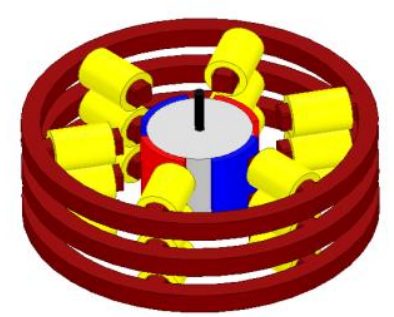

Şekil 4. Küresel motorun genel yapısı

\section{Küresel Motorun Elektromanyetik Analizleri}

Küresel motorun moment değerinin bilinmesi veya hesaplanarak bulunması, küresel motorun parametrelerinin gerektiğinde düzenlenmesi ve kontrolünün yapılabilmesi için önemli bir kriterdir. SEY kullanılarak elektromanyetik analizlerin gerçekleştirildiği ANSYS Maxwell yazılımında, küresel motorun üretmiş olduğu moment parametresi Lorentz kuvveti ve zahiri iş momenti olmak üzere iki farklı yöntemle elde edilebilmektedir. 
Bobin sarılı bir nüve ile sargı arasındaki hava aralığında, bobinden akım geçtiğinde, sargıdan nüveye doğru bir kuvvetin etki ettiği görülür. Elektromekanik sistemde kuvvet ve moment oluşan manyetik enerjiden meydana gelmektedir. Manyetik enerji yoğunluğu Eşitlik 1 ile hesaplanır (Öner, 2004).

$$
W_{m}=\int H * d v
$$

Sargılara verilen akım $(i$ ) ve bu akım sayesinde oluşan manyetik enerji yoğunluğu kullanılarak, moment ve kuvvet ifadeleri, mesafe $(s)$ ve dönme açısına $(\theta)$ bağlı olarak aşağıda verilen Eşitlik 2 ve Eşitlik 3 ile hesaplanabilir (Öner, 2004).

$$
\begin{aligned}
& T=\frac{d W(\theta, i)}{d \theta} \\
& F=\frac{d W(s, i)}{d s}
\end{aligned}
$$

Moment ve kuvvet parametrelerinin iyileştirilmesinde, küresel motoru oluşturan yapıların malzeme bilgileri, sargılara uygulanan akım değeri ve tasarımın boyutu gibi birçok parametre etkili olmaktadır. Küresel motor tasarımında, en iyi motor performansına ulaşmak için gerekli olan moment, kuvvet, adım açısı ve eksenel hareket kolaylığını sağlayacak değerlerin elde edilmesi gereklidir. Bu sebeple bu çalışmada, küresel motor yapısında yer alan mıknatıs malzemesini, mıknatıs yapısını ve stator ile rotor yapılarında kullanılan malzemeleri kapsayan çok farklı optimizasyon çalışmalarını içeren elektromanyetik analizler gerçekleştirilmiştir.,

Statik elektromanyetik analizde uyarma olarak sargılara amper-sarım cinsinden değerler tanımlanması gerekmektedir. Bu sebeple küresel motorun statorunda yer alan tüm sargıların 90 sarımdan oluştuğu tanımlanmış ve daha sonra istenen hareket yönüne bağlı olarak belirli sargılara 1A'lik akım verilerek uyarmaları sağlanmıştır.

Küresel motor üç boyutlu hareket kabiliyetine sahiptir. Bu sebeple motorun rotorunun koordinat sisteminde orjinde yer aldığ 1 düşünülerek, motorun $\mathrm{X}$ ve $\mathrm{Y}$ eksenlerinin pozitif ve negatif yöndeki hareketinin açılarının değişimlerine göre, $45^{\circ}$ lik açısal hareketler yaptırılmış ve her eksenel hareket için de elektromanyetik analizler gerçekleştirilmiştir. Analizlerde yer alan $\alpha$ değeri, küresel motorun yaptığı açısal hareketleri tanımlamaktadır ve yukarıda da bahsedildiği gibi küresel motorun hareketi $\alpha= \pm 45^{\circ}$ arasında değişmektedir. Elektromanyetik analizlerle, $\alpha$ 'nın bu değişimlerine göre küresel motorun manyetik akı yoğunluğu dağılımları ve moment değerleri elde edilmiştir.

Küresel motorun konumunun kartezyen koordinat sistemindeki konumuna göre, pozitif $\mathrm{X}$ ve $\mathrm{Y}$ ile negatif $\mathrm{X}$ ve $\mathrm{Y}$ yönlerindeki hareketlerini yapmadan önce, küresel motorun statik olarak konumlandığ $\alpha=0^{\circ}$ olan ilk durumu ve $\alpha=45^{\circ}$ olan son durumunun analizleri gerçekleştirilmiştir.

Küresel motorun bulunduğu koordinat sistemi referans alındığında pozitif X yönünde hareketini sağlamak için 2 Alt, 3 Alt, 5 Alt, 6 Alt ve 2 Üst, 3 Üst, 5 Üst, 6 Üst sargıları enerjilendirildiğinde, 5 Alt, 6 Alt, 5 Üst, 6 Üst sargıları karşısındaki S kutbunu itecek ve 2 Alt, 3 Alt, 2 Üst, 3 Üst sargıları karşısındaki S kutbunu kendi eksen doğrultusuna çekmek isteyeceklerdir. Hem 2 Alt ile 3 Alt, hem 2 Üst ile 3 Üst sargıları çekeceği için küresel motor bu dört kuvvetin bileşkesinde maksimum $45^{\circ}$ lik açı ile hareket edecektir. Küresel motorun hareket yönüne göre orta bobinler enerjilendirilerek, motorun hareket konumunda sabit kalması sağlanacaktır. Küresel motorun kartezyen koordinat sistemindeki konumuna göre pozitif X ve $\mathrm{Y}$ ile negatif $\mathrm{X}$ ve $\mathrm{Y}$ yönlerindeki hareketlerinin sağlanması için enerjilendirilmesi gereken stator sargıları ve hareket yönleri Şekil 5'te gösterilmiştir.

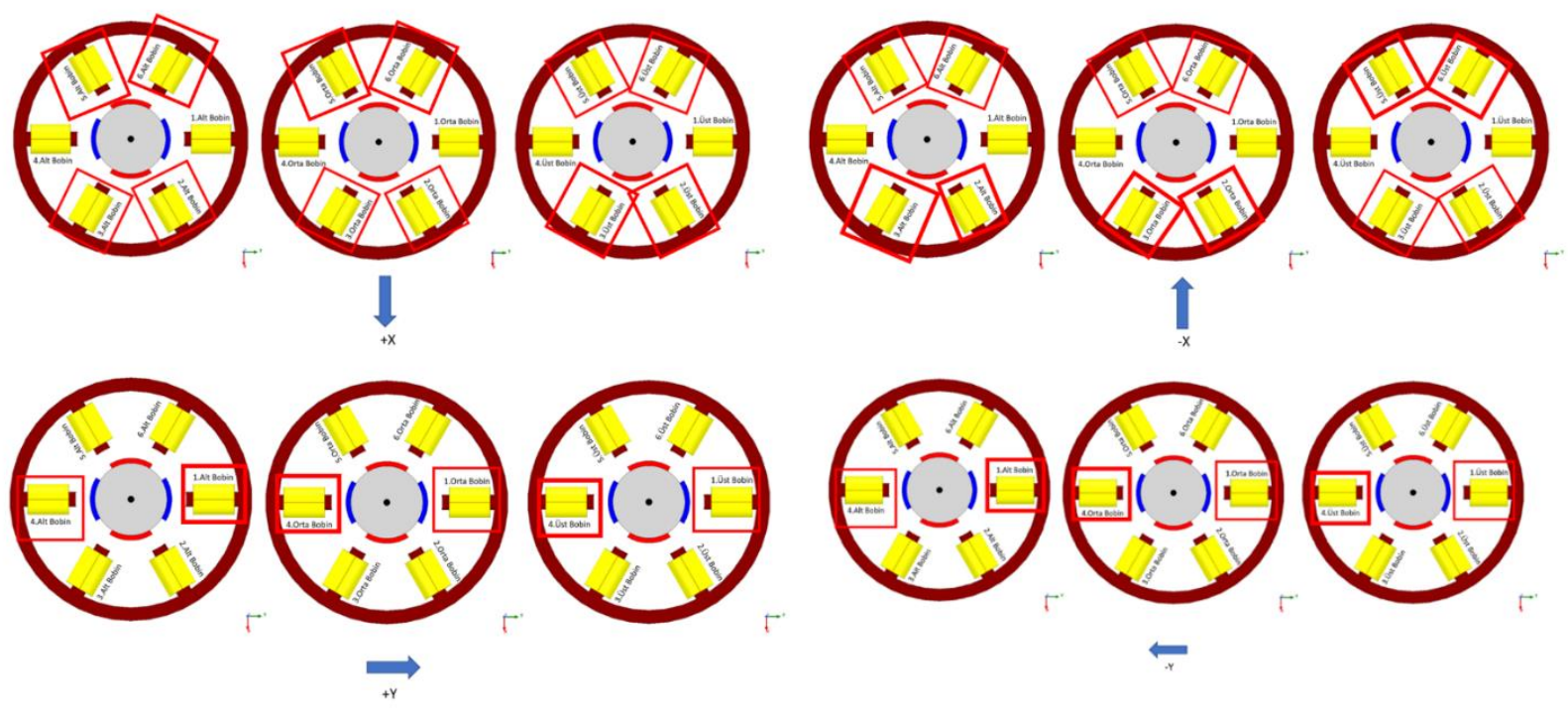

Şekil 5. Küresel motorun pozitif X ve Y ile negatif X ve Y eksenlerine doğru hareketi ve enerjilenen stator sarglları

$\mathrm{Bu}$ çalışmada küresel motorun pozitif $\mathrm{X}$ ve $\mathrm{Y}$ ile negatif $\mathrm{X}$ ve $\mathrm{Y}$ yönlerinde; mıknatısların NdFe30, NdFe35, SmCo28 malzemelerden oluştuğu ve mıknatıs yapısının gömülü düz mıknatıs, gömülü V-tipi mıknatıs, yüzey mıknatıs olduğu; stator ve rotor 
yapılarının steel_1008, M43_24G, JFE_Steel_50JNE300 malzemelerden oluştuğu modellerin, $\alpha=45^{\circ}$ hareket pozisyonlarındaki elektromanyetik analizleriyle, manyetik akı yoğunluğu dağılımları, kuvvet değerleri ve moment değerleri elde edilmiştir. $\alpha$ değeri eksenlere ve bileşkelerine doğru küresel motorun yaptığı açısal hareketleri tanımlamaktadır. Küresel motorun hareketi $\alpha= \pm 45^{\circ}$ arası değişmektedir.

Aşağıda, motorun rotorunda yer alan mıknatısların yerleşim şekli referans alınarak oluşturulan modellerin her biri için yapılan analizler ve bu analizlerden elde edilen manyetik akı yoğunluğu dağılımları, kuvvet ve moment değerleri; gömülü düz mıknatıs, gömülü V-tipi mıknatıs ve yüzey mıknatıs yerleşim şekilleri için sırasıyla verilmiş̧ir.

\subsection{Küresel Motorun Gömülü Düz Mıknatıs Yapısında Elektromanyetik Analizleri}

Bu analiz çalışmasında rotordaki mıknatıs yerleşiminin gömülü düz mıknatıs yapısında olduğu durum referans alınmıştır. Bu durum için; küresel motorun pozitif $\mathrm{X}$ ve $\mathrm{Y}$ ile negatif $\mathrm{X}$ ve $\mathrm{Y}$ yönlerinde ve bileşkelerinde olduğu; mıknatıların $\mathrm{NdFe} 30, \mathrm{NdFe} 35$, SmCo28 malzemelerden oluştuğu; stator ve rotor yapılarının ise steel_1008, M43_24G, JFE_Steel_50JNE300 malzemelerden oluştuğu modellerin $\alpha=45^{\circ}$ hareket pozisyonlarındaki elektromanyetik analizleri gerçekleştiriilmiştir. Her bir durum için manyetik akı yoğunluğu dağılımları, mıknatıs ve rotor ile stator yapılarında kullanılan malzemelere göre sırasıyla Şekil 6'da, Şekil 7'de ve Şekil 8'de gösterilmiştir.
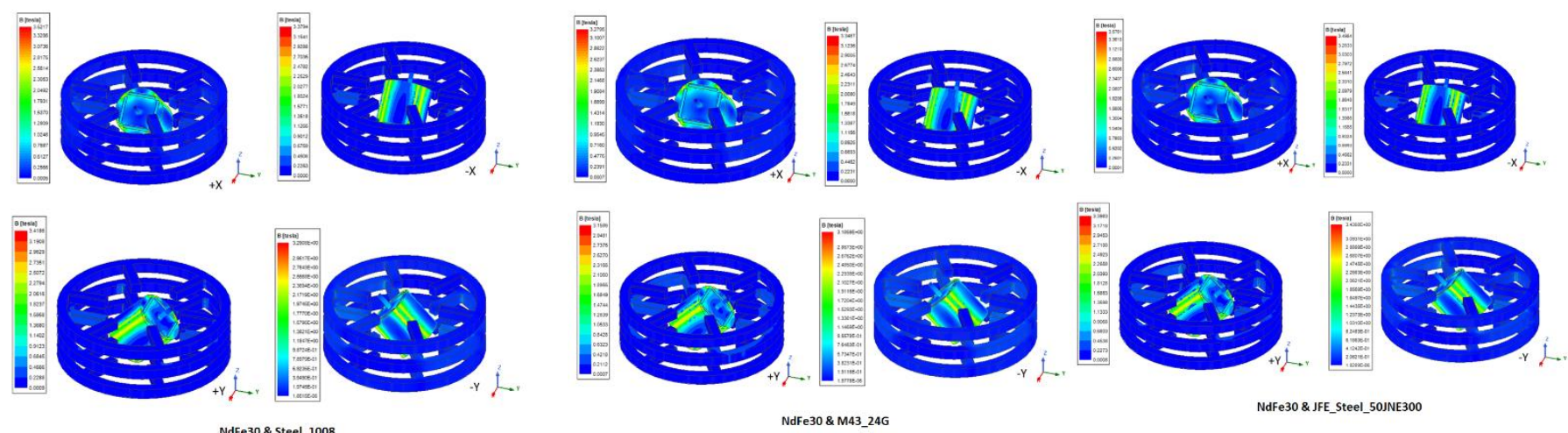

NdFe 30 \& M43_246

NdFe30 \& JfE_Steel_50JNE300

Şekil 6. Mıknatısların gömülü düz mıknatıs yapısında, NdFe30 mıknatıs ve rotor ile stator bileşenlerinde steel_1008, M43_24G, $J F E \_S t e e l \_50 J N E 300$ malzemeleri kullanılan küresel motorun, pozitif $X$ ve Y ile negatif $X$ ve Y yönlerinde, $\alpha=45^{\circ}$ hareket konumlarındaki manyetik akı yoğunluğu dă̆glımları
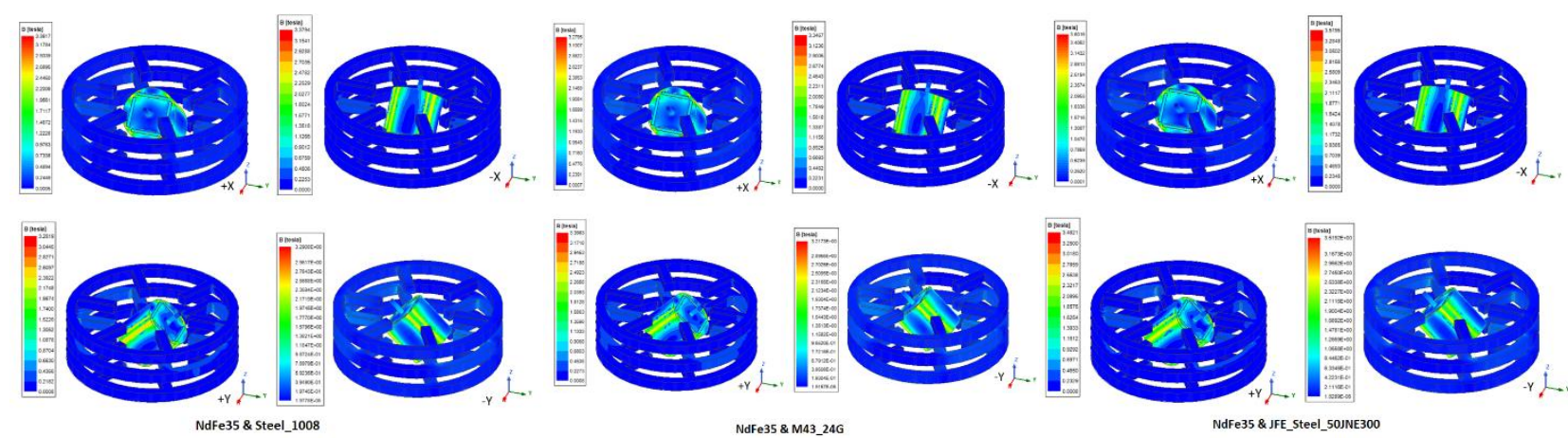

NdFe35 \& M43_24G
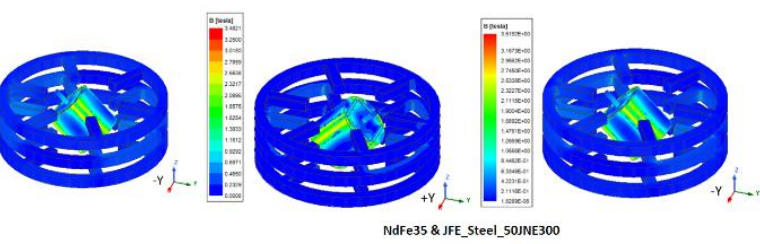

Şekil 7. Mıknatısların gömülü düz mıknatıs yapısında, NdFe35 mıknatıs ve rotor ile stator bileşenlerinde steel_1008, M43_24G, $J F E \_S t e e l \_50 J N E 300$ malzemeleri kullanılan küresel motorun, pozitif $X$ ve Y ile negatif $X$ ve $Y$ yönlerinde, $\alpha=45^{\circ}$ hareket konumlarındaki manyetik akı yoğunluğu dă̆llımları 


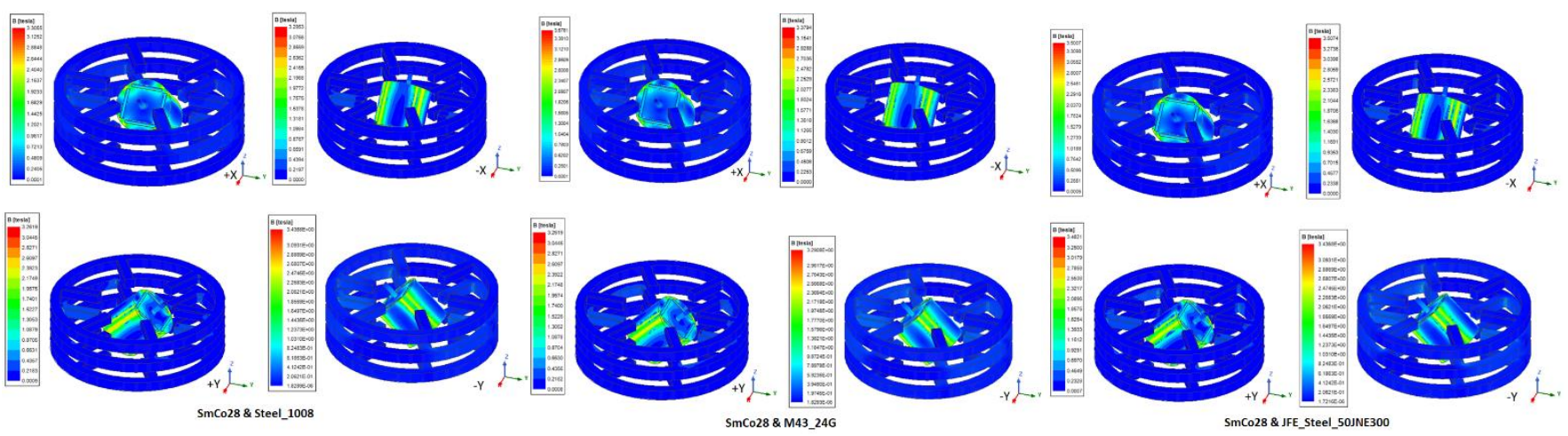

Şekil 8. Mıknatısların gömülü düz mıknatıs yapısında, SmCo28 mıknatıs ve rotor ile stator bileşenlerinde steel_1008, M43_24G, $J F E \_S t e e l \_50 J N E 300$ malzemeleri kullanılan küresel motorun, pozitif $X$ ve Y ile negatif $X$ ve Y yönlerinde, $\alpha=45^{\circ}$ hareket konumlarındaki manyetik akı yoğunluğu dağılımları

Yukarıda Şekil 6'da, Şekil 7'de ve Şekil 8'de manyetik akı yoğunluğu dağılımları verilen motor tasarımlarının her biri için, mıknatısların NdFe30, NdFe35, SmCo28 malzemelerden oluştuğu ve mıknatıs yapısının gömülü düz mıknatıs yapıda olduğu; stator ve rotor yapılarının steel_1008, M43_24G,JFE_Steel_50JNE300 malzemelerden oluştuğu modellerin kuvvet ve moment değerleri, mıknatıs ile rotor ve stator yapılarında kullanılan malzemelere göre sırasıyla Tablo 1'de, Tablo 2'de ve Tablo 3'te verildiği gibi elde edilmiştir.

Tablo 1. Miknatısların gömülü düz mıknatıs yapısında ve NdFe30 mıknatıs malzemesinden olduğu kuvvet ve moment değerleri

\begin{tabular}{l|c|c|c|c}
\hline Steel_1008 & $(+) \mathrm{X}$ & $(-) \mathrm{X}$ & $(+) \mathrm{Y}$ & $(-) \mathrm{Y}$ \\
\hline Kuvvet & $22 \mathrm{~N}$ & $23 \mathrm{~N}$ & $27 \mathrm{~N}$ & $26 \mathrm{~N}$ \\
\hline Moment & $3 \mathrm{mNm}$ & $1 \mathrm{mNm}$ & $2 \mathrm{mNm}$ & $9 \mathrm{mNm}$ \\
\hline M43_24G & $(+) \mathrm{X}$ & $(-) \mathrm{X}$ & $(+) \mathrm{Y}$ & $(-) \mathrm{Y}$ \\
\hline Kuvvet & $24 \mathrm{~N}$ & $25 \mathrm{~N}$ & $25 \mathrm{~N}$ & $31 \mathrm{~N}$ \\
\hline Moment & $6 \mathrm{mNm}$ & $11 \mathrm{mNm}$ & $5 \mathrm{mNm}$ & $9 \mathrm{mNm}$ \\
\hline JFE_Steel_50JNE300 & $(+) \mathrm{X}$ & $(-) \mathrm{X}$ & $(+) \mathrm{Y}$ & $(-) \mathrm{Y}$ \\
\hline Kuvvet & $22 \mathrm{~N}$ & $23 \mathrm{~N}$ & $21 \mathrm{~N}$ & $28 \mathrm{~N}$ \\
\hline Moment & $3 \mathrm{mNm}$ & $1.4 \mathrm{mNm}$ & $4 \mathrm{mNm}$ & $8 \mathrm{mNm}$ \\
\hline
\end{tabular}

Tablo 2. Mıknatısların gömülü düz mıknatıs yapısında ve NdFe35 mıknatıs malzemesinden olduğu kuvvet ve moment değerleri

\begin{tabular}{l|c|c|c|c}
\hline Steel_1008 & $(+) \mathrm{X}$ & $(-) \mathrm{X}$ & $(+) \mathrm{Y}$ & $(-) \mathrm{Y}$ \\
\hline Kuvvet & $34 \mathrm{~N}$ & $34 \mathrm{~N}$ & $33 \mathrm{~N}$ & $39 \mathrm{~N}$ \\
\hline Moment & $1.45 \mathrm{mNm}$ & $1.7 \mathrm{mNm}$ & $7 \mathrm{mNm}$ & $12 \mathrm{mNm}$ \\
\hline M43_24G & $(+) \mathrm{X}$ & $(-) \mathrm{X}$ & $(+) \mathrm{Y}$ & $(-) \mathrm{Y}$ \\
\hline Kuvvet & $35 \mathrm{~N}$ & $35 \mathrm{~N}$ & $35 \mathrm{~N}$ & $13 \mathrm{mNm}$ \\
\hline Moment & $0.5 \mathrm{mNm}$ & $1.8 \mathrm{mNm}$ & $7 \mathrm{mNm}$ & $(-) \mathrm{Y}$ \\
\hline JFE_Steel_50JNE300 & $(+) \mathrm{X}$ & $(-) \mathrm{X}$ & $(+) \mathrm{Y}$ & $36 \mathrm{~N}$ \\
\hline Kuvvet & $30 \mathrm{~N}$ & $28 \mathrm{~N}$ & $31 \mathrm{~N}$ & $12 \mathrm{mNm}$ \\
\hline Moment & $0.2 \mathrm{mNm}$ & $2.2 \mathrm{mNm}$ & $5 \mathrm{mNm}$ &
\end{tabular}


Tablo 3. Mıknatısların gömülü düz mıknatıs yapısında ve SmCo28 malzemesinden olduğu kuvvet ve moment değerleri

\begin{tabular}{l|c|c|c|c}
\hline Steel_1008 & $(+) \mathrm{X}$ & $(-) \mathrm{X}$ & $(+) \mathrm{Y}$ & $(-) \mathrm{Y}$ \\
\hline Kuvvet & $21 \mathrm{~N}$ & $21 \mathrm{~N}$ & $19 \mathrm{~N}$ & $25 \mathrm{~N}$ \\
\hline Moment & $3.5 \mathrm{mNm}$ & $1.6 \mathrm{mNm}$ & $3 \mathrm{mNm}$ & $6 \mathrm{mNm}$ \\
\hline M43_24G & $(+) \mathrm{X}$ & $(-) \mathrm{X}$ & $(+) \mathrm{Y}$ & $(-) \mathrm{Y}$ \\
\hline Kuvvet & $24 \mathrm{~N}$ & $23 \mathrm{~N}$ & $22 \mathrm{~N}$ & $28 \mathrm{~N}$ \\
\hline Moment & $2.3 \mathrm{mNm}$ & $1.8 \mathrm{mNm}$ & $5 \mathrm{mNm}$ & $8 \mathrm{mNm}$ \\
\hline JFE_Steel_50JNE300 & $(+) \mathrm{X}$ & $(-) \mathrm{X}$ & $(+) \mathrm{Y}$ & $(-) \mathrm{Y}$ \\
\hline Kuvvet & $21 \mathrm{~N}$ & $22 \mathrm{~N}$ & $19 \mathrm{~N}$ & $25 \mathrm{~N}$ \\
\hline Moment & $1.7 \mathrm{mNm}$ & $1.3 \mathrm{mNm}$ & $4 \mathrm{mNm}$ & $7 \mathrm{mNm}$ \\
\hline
\end{tabular}

\subsection{Küresel Motorun Gömülü V-tipi Mıknatıs Yapısında Elektromanyetik Analizleri}

$\mathrm{Bu}$ analiz çalışmasında rotordaki mıknatıs yerleşiminin gömülü V-tipi mıknatıs yapısında olduğu durum referans alınmıştır. Bu durum için küresel motorun pozitif $\mathrm{X}$ ve $\mathrm{Y}$ ile negatif $\mathrm{X}$ ve Y yönlerinde ve bileşkelerinde olduğu; mıknatısların NdFe30, NdFe35, SmCo28 malzemelerden oluştuğu; stator ve rotor yapılarının steel_1008, M43_24G, JFE_Steel_50JNE300 malzemelerden oluştuğu modellerin $\alpha=45^{\circ}$ hareket pozisyonlarındaki elektromanyetik analizleri gerçekleştirilmiştir. Her bir durum için manyetik akı yoğunluğu dağılımları, mıknatıs ve rotor ile stator yapılarında kullanılan malzemelere göre sirasıyla Şekil 9'da, Şekil 10'da ve Şekil 11'de gösterilmiştir.

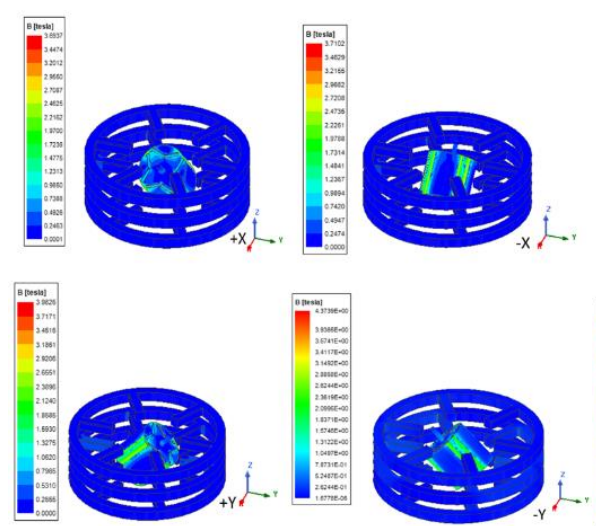

NdFe30 \& Steel_ 1008
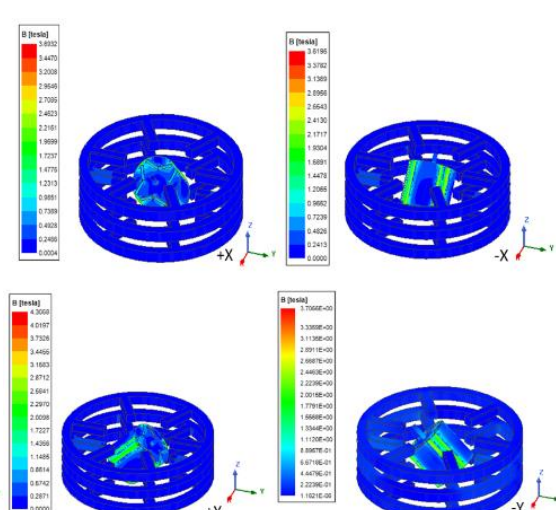

NdFe $30 \&$ M43_24G
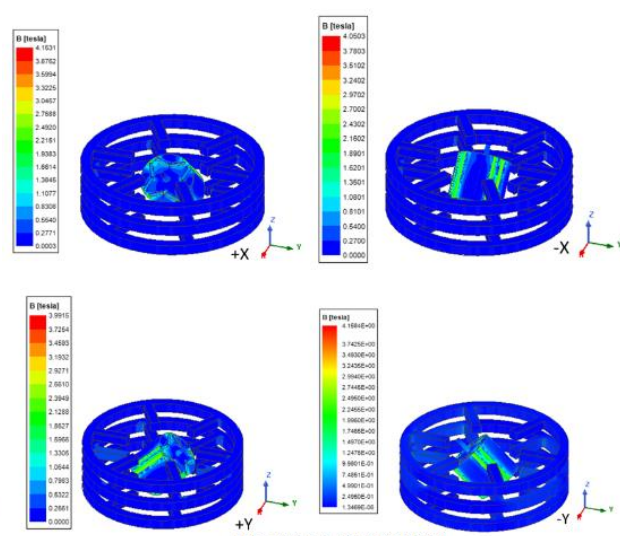

NdFe30 \& JFE_Steel_50JNE300

Şekil 9. Miknatısların gömülü V-tipi mıknatıs yapısında, NdFe30 mıknatıs ve rotor ile stator bileşenlerinde steel_1008, M43_24G, JFE_Steel_50JNE300 malzemeleri kullanılan küresel motorun, pozitif X ve Y ile negatif X ve Y yönlerinde, $\alpha=45^{\circ}$ hareket konumlarındaki manyetik akı yoğunluğu dă̆llımları
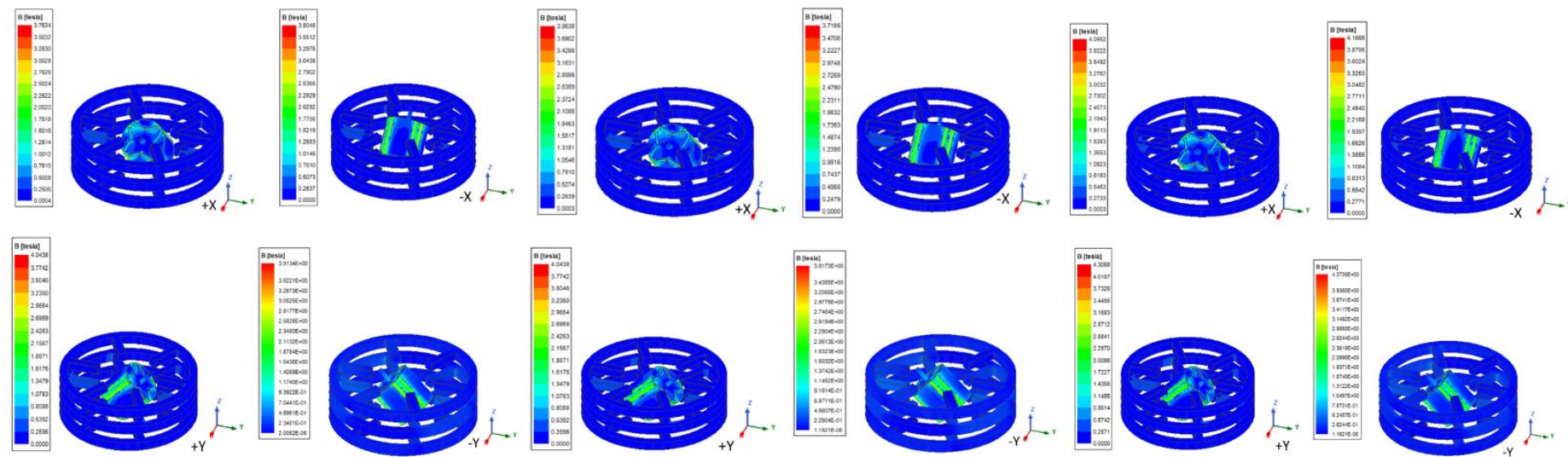

NdFe35 \& M43_24G

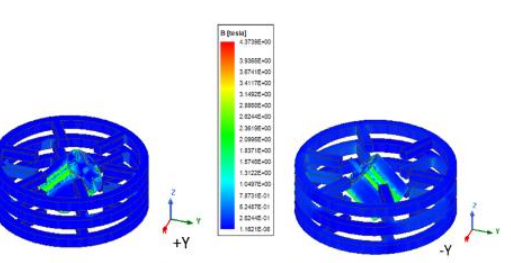

NdFe35 \& JFE_Steel_50JNE300

Şekil 10. Mıknatısların gömülü V-tipi mıknatıs yapısında, NdFe35 mıknatıs ve rotor ile stator bileşenlerinde steel_1008, M43_24G,

JFE_Steel_50JNE300 malzemeleri kullanılan küresel motorun, pozitif X ve Y ile negatif X ve Y yönlerinde, $\alpha=45^{\circ}$ hareket konumlarındaki manyetik akı yoğunluğu dă̆llımları 

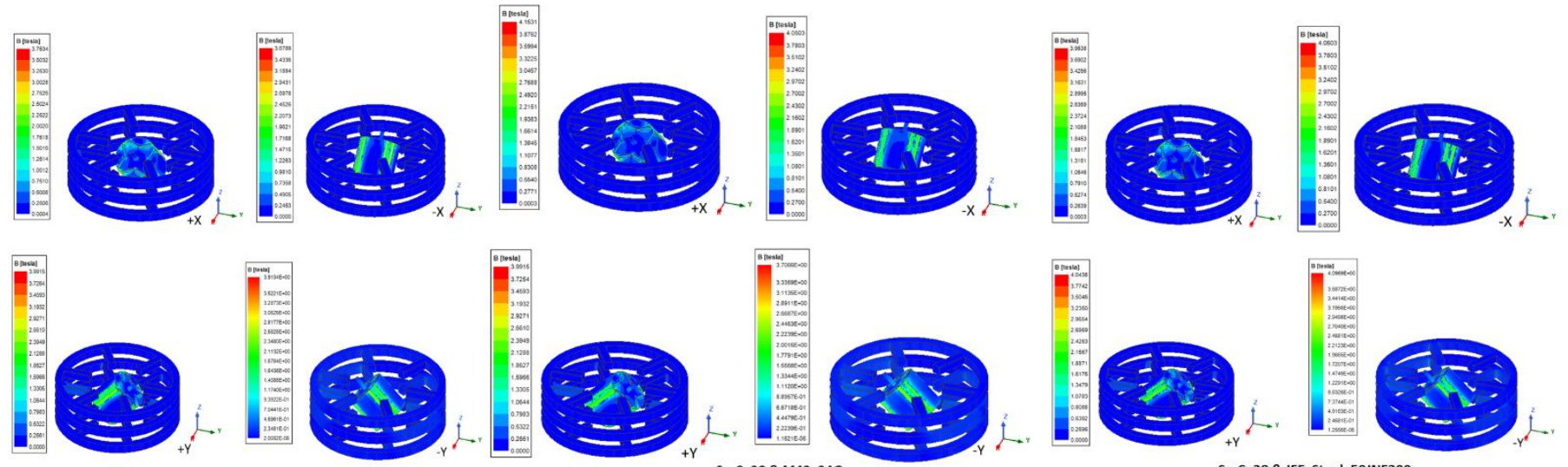

SmC028\& M43_24G

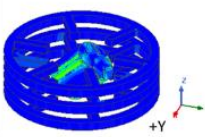

SmC028 \& JFE_Steel_50JNE300

Şekil 11. Miknatısların gömülü V-tipi mıknatıs yapısında,SmCo28 miknatıs ve rotor ile stator bileşenlerinde steel_1008, M43_24G, JFE_Steel_50JNE300 malzemeleri kullanılan küresel motorun, pozitif X ve Y ile negatif X ve Y yönlerinde, $\alpha=45^{\circ}$ hareket konumlarındaki manyetik akı yoğunluğu dă̆llımları

Yukarıda Şekil 9'da, Şekil 10'da ve Şekil 11'de manyetik akı yoğunluğu dağılımları verilen motor tasarımlarının her biri için, mıknatısların NdFe30, NdFe35, SmCo28 malzemelerden oluştuğu ve mıknatıs yapısının gömülü V-tipi mıknatıs yapıda olduğu; stator ve rotor yapılarının steel_1008, M43_24G,JFE_Steel_50JNE300 malzemelerden oluştuğu modellerin kuvvet ve moment değerleri, mıknatıs ve rotor ile stator yapılarında kullanılan malzemelere göre sırasıyla Tablo 4'te, Tablo 5 'te ve Tablo 6'da gösterildiği gibi elde edilmiştir.

Tablo 1. Mıknatısların gömülü V-tipi mıknatıs yapısında ve NdFe30 mıknatıs malzemesinden olduğu kuvvet ve moment değerleri

\begin{tabular}{l|c|c|c|c}
\hline Steel_1008 & $(+) \mathrm{X}$ & $(-) \mathrm{X}$ & $(+) \mathrm{Y}$ & $(-) \mathrm{Y}$ \\
\hline Kuvvet & $20 \mathrm{~N}$ & $12 \mathrm{~N}$ & $14 \mathrm{~N}$ & $20 \mathrm{~N}$ \\
\hline Moment & $5 \mathrm{mNm}$ & $1.8 \mathrm{mNm}$ & $1 \mathrm{mNm}$ & $2.5 \mathrm{mNm}$ \\
\hline M43_24G & $(+) \mathrm{X}$ & $(-) \mathrm{X}$ & $(+) \mathrm{Y}$ & $(-) \mathrm{Y}$ \\
\hline Kuvvet & $37 \mathrm{~N}$ & $8 \mathrm{~N}$ & $8 \mathrm{~N}$ & $11 \mathrm{~N}$ \\
\hline Moment & $6 \mathrm{mNm}$ & $1 \mathrm{mNm}$ & $6 \mathrm{mNm}$ & $6 \mathrm{mNm}$ \\
\hline JFE_Steel_50JNE300 & $(+) \mathrm{X}$ & $(-) \mathrm{X}$ & $(+) \mathrm{Y}$ & $(-) \mathrm{Y}$ \\
\hline Kuvvet & $43 \mathrm{~N}$ & $28 \mathrm{~N}$ & $14 \mathrm{~N}$ & $30 \mathrm{~N}$ \\
\hline Moment & $4 \mathrm{mNm}$ & $3.3 \mathrm{mNm}$ & $2.5 \mathrm{mNm}$ & $4 \mathrm{mNm}$ \\
\hline
\end{tabular}

Tablo 2. Mıknatısların gömülü V-tipi mıknatıs yapısında ve NdFe35 mıknatıs malzemesinden olduğu kuvvet ve moment değerleri

\begin{tabular}{l|c|c|c|c}
\hline Steel_1008 & $(+) \mathrm{X}$ & $(-) \mathrm{X}$ & $(+) \mathrm{Y}$ & $(-) \mathrm{Y}$ \\
\hline Kuvvet & $18 \mathrm{~N}$ & $5 \mathrm{~N}$ & $9 \mathrm{~N}$ & $13 \mathrm{~N}$ \\
\hline Moment & $4.5 \mathrm{mNm}$ & $2.8 \mathrm{mNm}$ & $3.8 \mathrm{mNm}$ & $2.8 \mathrm{mNm}$ \\
\hline M43_24G & $(+) \mathrm{X}$ & $(-) \mathrm{X}$ & $(+) \mathrm{Y}$ & $(-) \mathrm{Y}$ \\
\hline Kuvvet & $33 \mathrm{~N}$ & $5 \mathrm{~N}$ & $9 \mathrm{~N}$ & $10 \mathrm{~N}$ \\
\hline Moment & $6.5 \mathrm{mNm}$ & $3 \mathrm{mNm}$ & $2.5 \mathrm{mNm}$ & $2.7 \mathrm{mNm}$ \\
\hline JFE_Steel_50JNE300 & $(+) \mathrm{X}$ & $(-) \mathrm{X}$ & $(+) \mathrm{Y}$ & $(-) \mathrm{Y}$ \\
\hline Kuvvet & $58 \mathrm{~N}$ & $18 \mathrm{~N}$ & $19 \mathrm{~N}$ & $26 \mathrm{~N}$ \\
\hline Moment & $7.5 \mathrm{mNm}$ & $5 \mathrm{mNm}$ & $0.4 \mathrm{mNm}$ & $6 \mathrm{mNm}$ \\
\hline
\end{tabular}


Tablo 3. Mıknatısların gömülü V-tipi mıknatıs yapısında ve SmCo28 mıknatıs malzemesinden olduğu kuvvet ve moment dĕ̌erleri

\begin{tabular}{l|c|c|c|c}
\hline Steel_1008 & $(+) \mathrm{X}$ & $(-) \mathrm{X}$ & $(+) \mathrm{Y}$ & $(-) \mathrm{Y}$ \\
\hline Kuvvet & $20 \mathrm{~N}$ & $14 \mathrm{~N}$ & $4 \mathrm{~N}$ & $22 \mathrm{~N}$ \\
\hline Moment & $1 \mathrm{mNm}$ & $1.5 \mathrm{mNm}$ & $5 \mathrm{mNm}$ & $5 \mathrm{mNm}$ \\
\hline M43_24G & $(+) \mathrm{X}$ & $(-) \mathrm{X}$ & $(+) \mathrm{Y}$ & $(-) \mathrm{Y}$ \\
\hline Kuvvet & $20 \mathrm{~N}$ & $12 \mathrm{~N}$ & $1 \mathrm{~N}$ & $18 \mathrm{~N}$ \\
\hline Moment & $6 \mathrm{mNm}$ & $1 \mathrm{mNm}$ & $2.5 \mathrm{mNm}$ & $2 \mathrm{mNm}$ \\
\hline JFE_Steel_50JNE300 & $(+) \mathrm{X}$ & $(-) \mathrm{X}$ & $(+) \mathrm{Y}$ & $(-) \mathrm{Y}$ \\
\hline Kuvvet & $36 \mathrm{~N}$ & $27 \mathrm{~N}$ & $14 \mathrm{~N}$ & $34 \mathrm{~N}$ \\
\hline Moment & $7 \mathrm{mNm}$ & $3 \mathrm{mNm}$ & $1.5 \mathrm{mNm}$ & $3 \mathrm{mNm}$ \\
\hline
\end{tabular}

\subsection{Küresel Motorun Yüzey Mıknatıs Yapısında Elektromanyetik Analizleri}

$\mathrm{Bu}$ analiz çalışmasında rotordaki mıknatıs yerleşiminin yüzey mıknatıs yapısında olduğu durum referans alınmıştır. Bu durum için; küresel motorun pozitif $\mathrm{X}$ ve $\mathrm{Y}$ ile negatif $\mathrm{X}$ ve $\mathrm{Y}$ yönlerinde ve bileşkelerinde olduğu; mıknatısların $\mathrm{NdFe} 30$, NdFe35, SmCo28 malzemelerden oluştuğu; stator ve rotor yapılarının ise steel_1008, M43_24G, JFE_Steel_50JNE300 malzemelerden oluştuğu modellerin $\alpha=45^{\circ}$ hareket pozisyonlarındaki elektromanyetik analizleri gerçekleştirilmiştir. Her bir durum için manyetik akı yoğunluğu dağılımları, mıknatıs ve rotor ile stator yapılarında kullanılan malzemelere göre sirasıyla Şekil 12'de, Şekil 13'te ve Şekil 14'te gösterilmiştir.
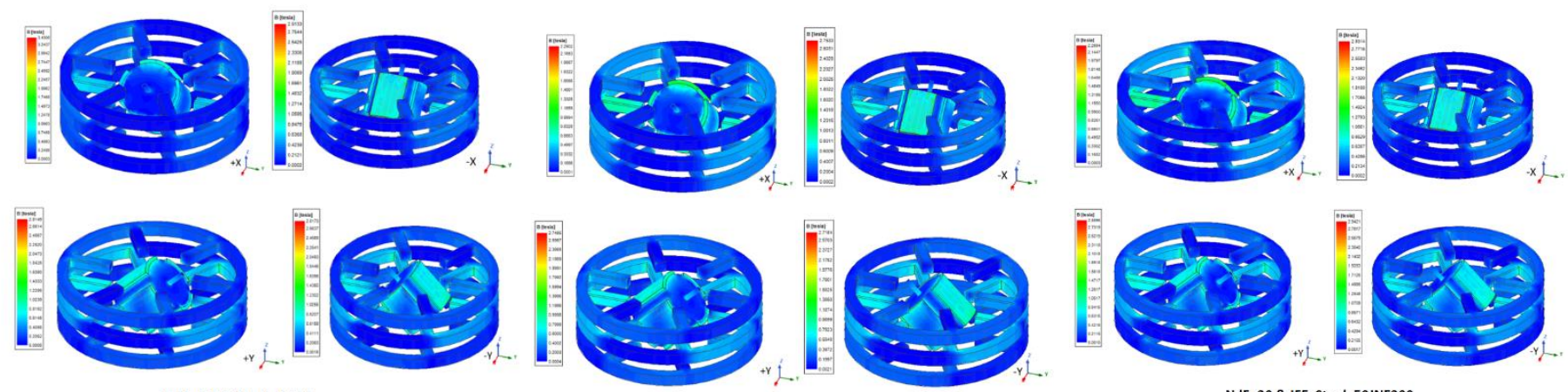

NdFe30 \& Steel_1008

NdFe 30 \& M43 $24 \mathrm{G}$

NdFe30 \& JFE_Steel_50JNE300

Şekil 12. Mıknatısların yüzey mıknatıs yapısında, NdFe30 mıknatıs ve rotor ile stator bileşenlerinde steel_1008, M43_24G, JFE_Steel_50JNE300 malzemeleri kullanılan küresel motorun, pozitif X ve Y ile negatif X ve Yyönlerinde, $\alpha=45^{\circ}$ hareket konumlarındaki manyetik akı yŏgunluğu dă̆llımları
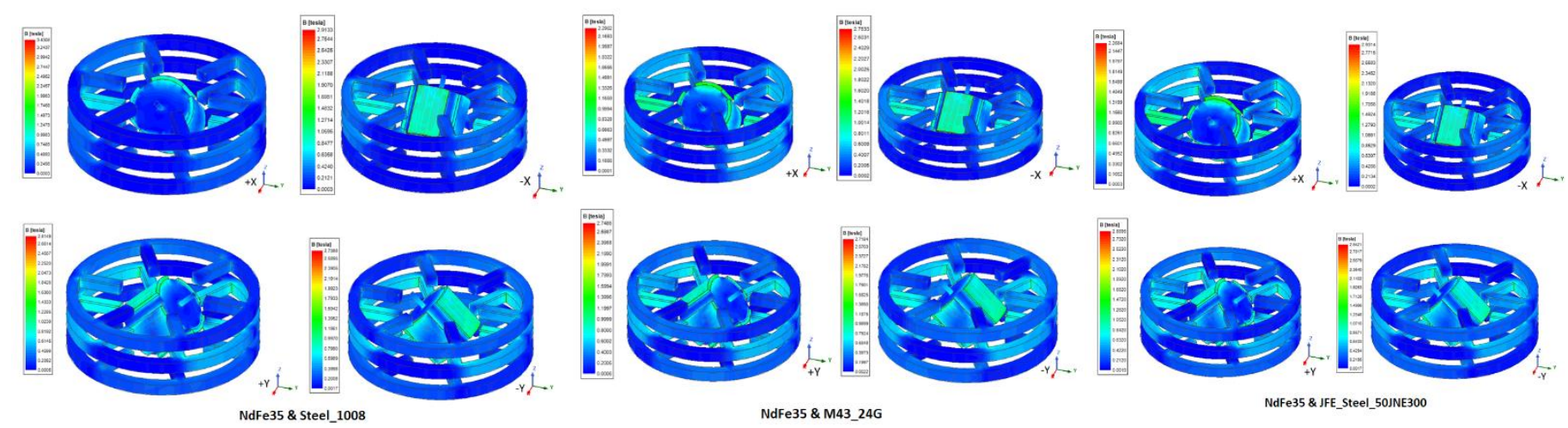

NdFe35 \& M43_24G

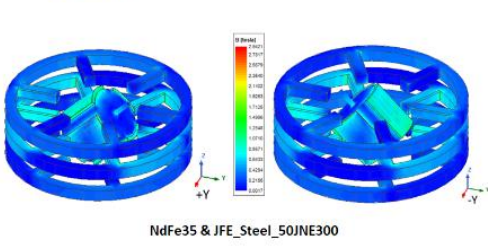

Şekil 13. Mıknatısların yüzey miknatıs yapısında, NdFe35 miknatıs ve rotor ile stator bileşenlerinde steel_1008, M43_24G, $J F E \_S t e e l \_50 J N E 300$ malzemeleri kullanulan küresel motorun, pozitif $X$ ve Y ile negatif $X$ ve $Y$ yönlerinde, $\alpha=45^{\circ}$ hareket konumlarındaki manyetik akı yoğunluğu dă̆ılımları 

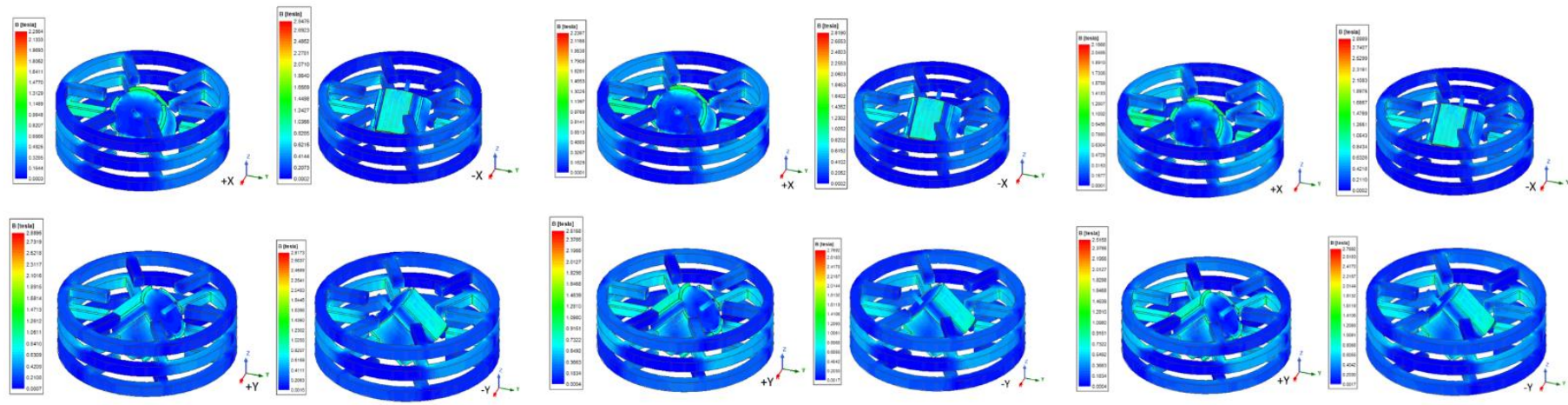

SmCo28 \& Steel_1008

SmCo28 \& M43_24G

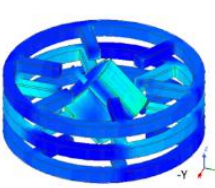

(2)

Şekil 14. Mıknatısların yüzey mıknatıs yapısında, SmCo28 miknatıs ve rotor ile stator bileşenlerinde steel_1008, M43_24G, $J F E \_S t e e l \_50 J N E 300$ malzemeleri kullanilan küresel motorun, pozitif $X$ ve Y ile negatif $X$ ve $Y$ yönlerinde, $\alpha=45^{\circ}$ hareket konumlarındaki manyetik akı yoğunluğu dă̆llımları

Yukarıda Şekil 12'de, Şekil 13'te ve Şekil 14'te manyetik akı yoğunluğu dağılımları verilen motor tasarımlarının her biri için, mıknatısların NdFe30, NdFe35, SmCo28 malzemelerden oluştuğu ve mıknatıs yapısının gömülü V-tipi mıknatıs yapıda olduğu; stator ve rotor yapılarının steel_1008, M43_24G, JFE_Steel_50JNE300 malzemelerden oluştuğu modellerin kuvvet ve moment değerleri, mıknatıs ve rotor ile stator yapılarında kullanılan malzemelere göre sırasıyla Tablo 7'de, Tablo 8'de ve Tablo 9'da gösterildiği gibi elde edilmiştir.

Tablo 7. Mıknatısların yüzey mıknatıs yapısında ve NdFe30 mıknatıs malzemesinden olduğu kuvvet ve moment değerleri

\begin{tabular}{l|c|c|c|c}
\hline Steel_1008 & $(+) \mathrm{X}$ & $(-) \mathrm{X}$ & $(+) \mathrm{Y}$ & $(-) \mathrm{Y}$ \\
\hline Kuvvet & $33 \mathrm{~N}$ & $38 \mathrm{~N}$ & $32 \mathrm{~N}$ & $32 \mathrm{~N}$ \\
\hline Moment & $0.56 \mathrm{mNm}$ & $0.96 \mathrm{mNm}$ & $0.56 \mathrm{mNm}$ & $0.56 \mathrm{mNm}$ \\
\hline M43_24G & $(+) \mathrm{X}$ & $(-) \mathrm{X}$ & $(+) \mathrm{Y}$ & $(-) \mathrm{Y}$ \\
\hline Kuvvet & $35 \mathrm{~N}$ & $40 \mathrm{~N}$ & $35 \mathrm{~N}$ & $35 \mathrm{~N}$ \\
\hline Moment & $0.576 \mathrm{mNm}$ & $0.96 \mathrm{mNm}$ & $0.57 \mathrm{mNm}$ & $0.57 \mathrm{mNm}$ \\
\hline JFE_Steel_50JNE300 & $(+) \mathrm{X}$ & $(-) \mathrm{X}$ & $(+) \mathrm{Y}$ & $(-) \mathrm{Y}$ \\
\hline Kuvvet & $35 \mathrm{~N}$ & $40 \mathrm{~N}$ & $36 \mathrm{~N}$ & $36 \mathrm{~N}$ \\
\hline Moment & $0.578 \mathrm{mNm}$ & $0.96 \mathrm{mNm}$ & $0.57 \mathrm{mNm}$ & $0.57 \mathrm{mNm}$ \\
\hline
\end{tabular}

Tablo 8. Mıknatısların yüzey mıknatıs yapısında ve NdFe35 mıknatıs malzemesinden olduğu kuvvet ve moment değerleri

\begin{tabular}{l|c|c|c|c}
\hline Steel_1008 & $(+) \mathrm{X}$ & $(-) \mathrm{X}$ & $(+) \mathrm{Y}$ & $(-) \mathrm{Y}$ \\
\hline Kuvvet & $43 \mathrm{~N}$ & $40 \mathrm{~N}$ & $43 \mathrm{~N}$ & $40 \mathrm{~N}$ \\
\hline Moment & $0.6 \mathrm{mNm}$ & $0.6 \mathrm{mNm}$ & $0.56 \mathrm{mNm}$ & $0.56 \mathrm{mNm}$ \\
\hline M43_24G & $(+) \mathrm{X}$ & $(-) \mathrm{X}$ & $(+) \mathrm{Y}$ & $(-) \mathrm{Y}$ \\
\hline Kuvvet & $45 \mathrm{~N}$ & $43 \mathrm{~N}$ & $44 \mathrm{~N}$ & $44 \mathrm{~N}$ \\
\hline Moment & $0.5 \mathrm{mNm}$ & $1 \mathrm{mNm}$ & $0.57 \mathrm{mNm}$ & $0.57 \mathrm{mNm}$ \\
\hline JFE_Steel_50JNE300 & $(+) \mathrm{X}$ & $(-) \mathrm{X}$ & $(+) \mathrm{Y}$ & $(-) \mathrm{Y}$ \\
\hline Kuvvet & $43 \mathrm{~N}$ & $40 \mathrm{~N}$ & $44 \mathrm{~N}$ & $44 \mathrm{~N}$ \\
\hline Moment & $0.4 \mathrm{mNm}$ & $0.3 \mathrm{mNm}$ & $0.57 \mathrm{mNm}$ & $0.57 \mathrm{mNm}$ \\
\hline
\end{tabular}


Tablo 9. Mıknatısların yüzey mıknatıs yapısında ve SmCo28 mıknatıs malzemesinden olduğu kuvvet ve moment değerleri

\begin{tabular}{l|c|c|c|c}
\hline Steel_1008 & $(+) \mathrm{X}$ & $(-) \mathrm{X}$ & $(+) \mathrm{Y}$ & $(-) \mathrm{Y}$ \\
\hline Kuvvet & $32 \mathrm{~N}$ & $36 \mathrm{~N}$ & $30 \mathrm{~N}$ & $32 \mathrm{~N}$ \\
\hline Moment & $0.53 \mathrm{mNm}$ & $0.9 \mathrm{mNm}$ & $0.56 \mathrm{mNm}$ & $0.56 \mathrm{mNm}$ \\
\hline M43_24G & $(+) \mathrm{X}$ & $(-) \mathrm{X}$ & $(+) \mathrm{Y}$ & $(-) \mathrm{Y}$ \\
\hline Kuvvet & $33.5 \mathrm{~N}$ & $38 \mathrm{~N}$ & $33 \mathrm{~N}$ & $34 \mathrm{~N}$ \\
\hline Moment & $0.54 \mathrm{mNm}$ & $0.9 \mathrm{mNm}$ & $0.57 \mathrm{mNm}$ & $0.57 \mathrm{mNm}$ \\
\hline JFE_Steel_50JNE300 & $(+) \mathrm{X}$ & $(-) \mathrm{X}$ & $(+) \mathrm{Y}$ & $(-) \mathrm{Y}$ \\
\hline Kuvvet & $32 \mathrm{~N}$ & $37 \mathrm{~N}$ & $33 \mathrm{~N}$ & $33 \mathrm{~N}$ \\
\hline Moment & $0.54 \mathrm{mNm}$ & $0.9 \mathrm{mNm}$ & $0.57 \mathrm{mNm}$ & $0.57 \mathrm{mNm}$ \\
\hline
\end{tabular}

\subsection{Küresel Motorun Farklı Mıknatıs Yapılarında ve Farklı Mıknatıs Türlerinde Gerçekleştirilen Elektromanyetik Analizlerinin Karşılaştırılması}

Motor yapısında farklı mıknatıs yerleşimleri ve farklı mıknatıs türleri ile rotorda ve statorda farklı malzemeler kullanılarak oluşturulan modeler için yapılan elektromanyetik analizler irdelendiğinde ve manyetik akı yoğunluğu dağılımları görsellerine bakıldığında mıknatıs yerleşiminin rotorun yüzeyinde olduğu ve NdFe35 malzemesinin kullanıldığı modelin manyetik akı yoğunluğunun en uygun değerde olduğu ve statorda manyetik doyum probleminin olmadığı gözlemlenmiştir.

Motorun farklı mıknatıs malzemeleri ve farklı mıknatıs yerleşimleri ile rotorda ve statorda farklı malzemeler kullanılarak oluşturulan modellerinin elektromanyetik analizlerleri ile kuvvet ve moment değerleri karşılaştırmalı olarak sırasıyla Şekil 15, Şekil 16 ve Şekil 17 'de verilmiştir.

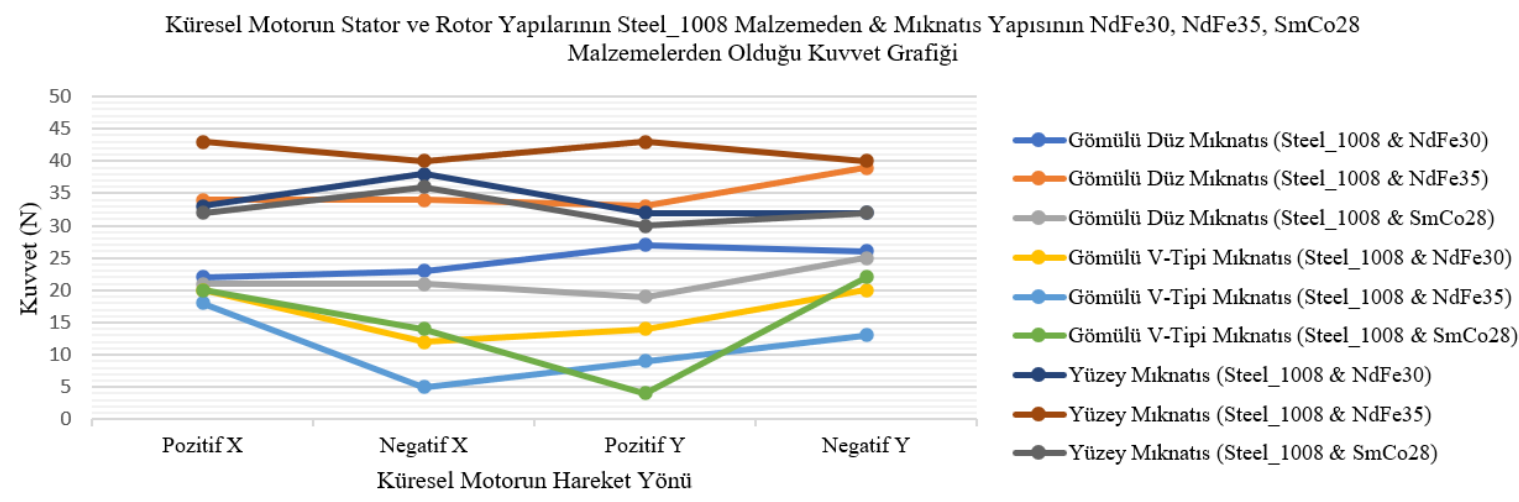

a)

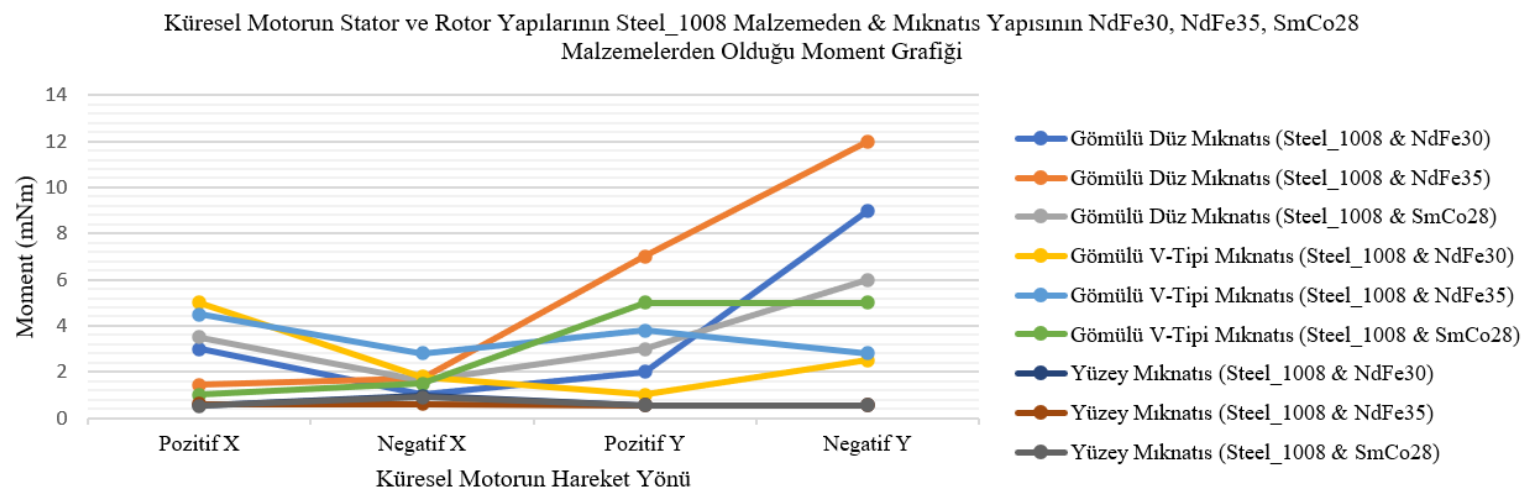

b)

Şekil 15. Miknatısların gömülü düz, gömülü V-tipi ve yüzey mıknatıs yapısında, NdFe30, NdFe35 ve SmCo28 mıknatıs malzemeleri ve rotor ile stator bileşenlerinde Steel_1008 malzemesi kullanılan küresel motorun, pozitif X ve Y ile negatif Xve Y yönlerinde, $\alpha=45^{\circ}$ hareket konumlarındaki karşılaş̧ırmalı a) kuvvet ve b) moment değerleri 


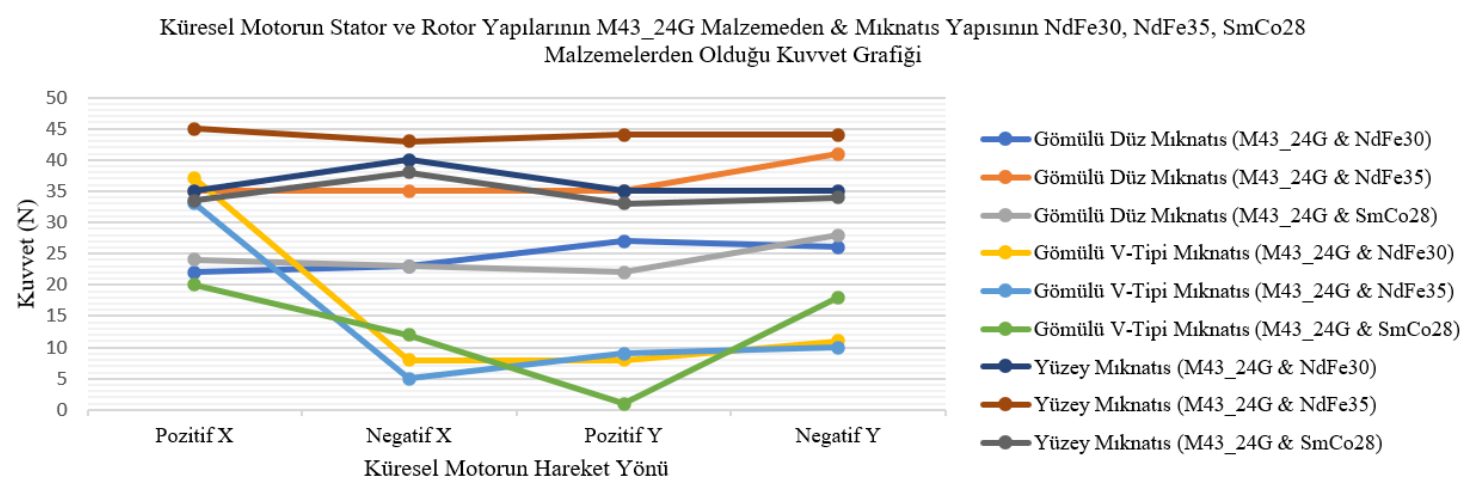

a)

Küresel Motorun Stator ve Rotor Yapılarının M43_24G Malzemeden \& Miknatıs Yapısının NdFe30, NdFe35, SmCo28 Malzemelerden Olduğu Moment Grafiği

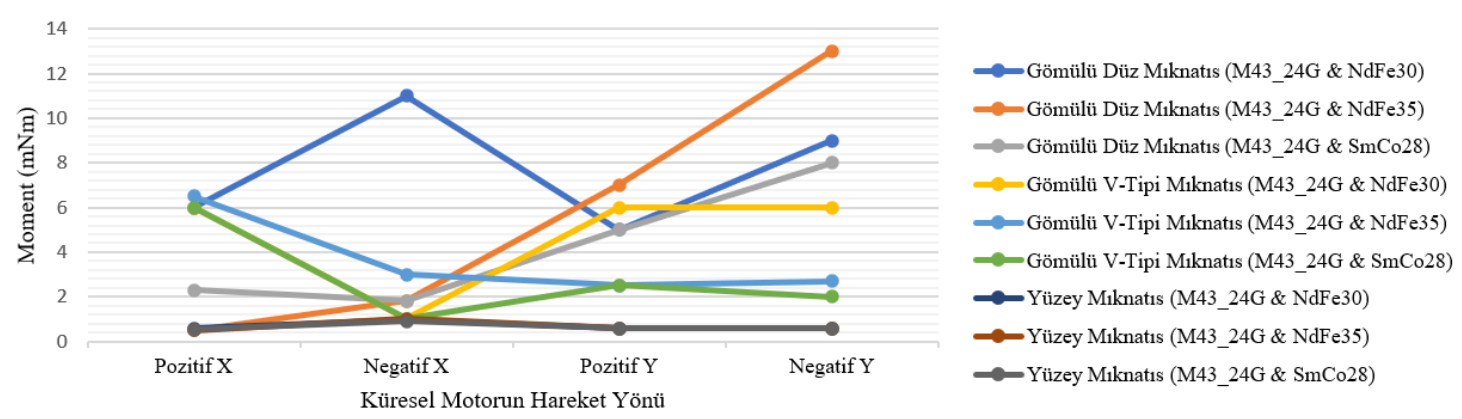

b)

Şekil 16. Miknatısların gömülü düz, gömülü V-tipi ve yüzey mıknatıs yapısında NdFe30, NdFe35 ve SmCo28 miknatıs malzemeleri ve rotor ile stator bileşenlerinde M43_24G malzemesi kullanılan küresel motorun, pozitif X ve Y ile negatif X ve Y yönlerinde, $\alpha=45^{\circ}$ hareket konumlarındaki karşılaştırmalı a) kuvvet ve b) moment değerleri

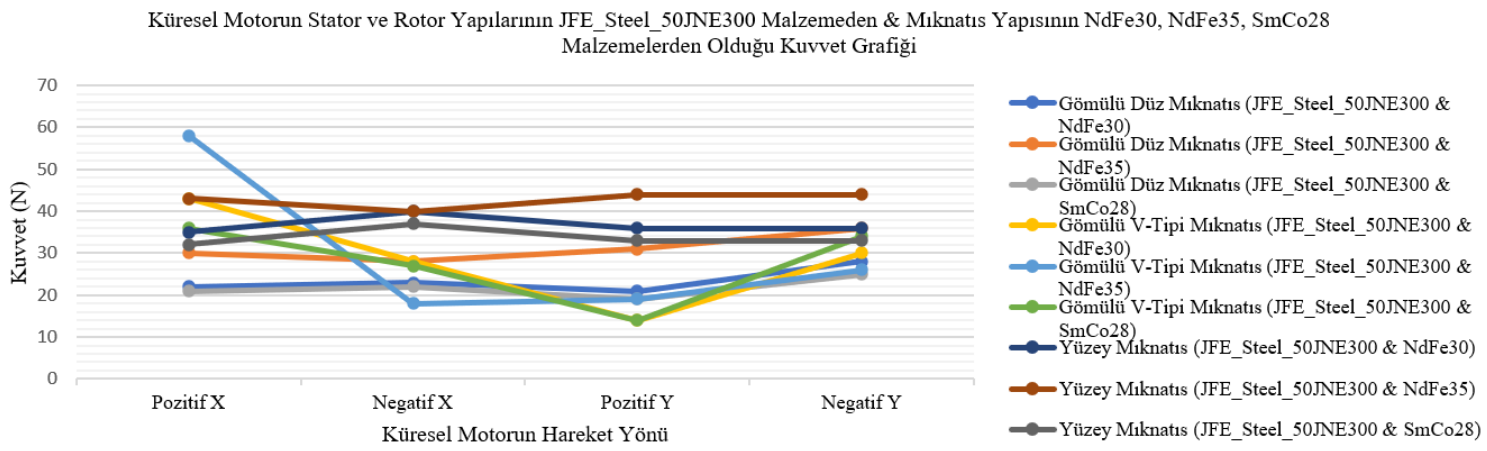

a)

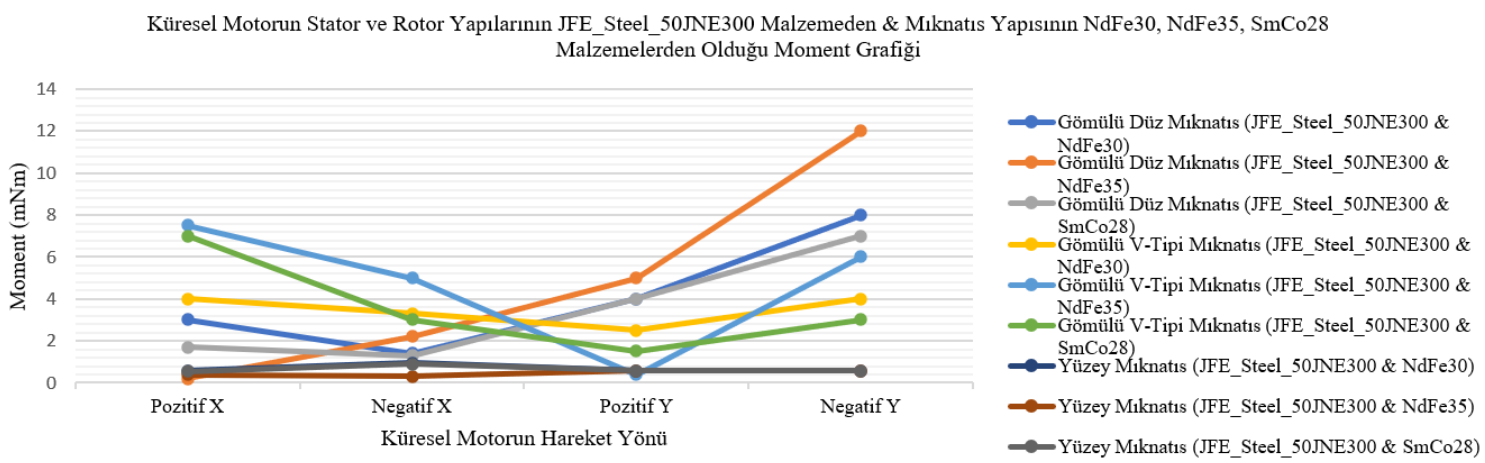

b)

Şekil 17. Miknatısların gömülü düz, gömülü V-tipi ve yüzey mıknatıs yapısında NdFe30, NdFe35 ve SmCo28 mıknatıs malzemeleri ve rotor ile stator bileşenlerinde JFE_Steel_50JNE300 malzemesi kullanılan küresel motorun, pozitif $X$ ve Y ile negatif $X$ ve $Y$ yönlerinde, $\alpha=45^{\circ}$ hareket konumlarındaki karşılaştırmalı a) kuvvet ve b) moment değerleri 
Elektromanyetik analizleri gerçekleştirilen ve yukarıda verilen 27 farklı motor modelinden elde edilen moment değerleri incelendiğinde, sonuçların $0,2 \mathrm{mNm}-12 \mathrm{mNm}$ arasında değiştiği ve $\mathrm{mNm}$ ölçeğinde önemli bir farklılık göstermediği görülmektedir. Motor modellerinin kuvvet analizlerinden elde edilen sonuçları karşılaştırıldığında ise, değerlerin $1 \mathrm{~N}-58 \mathrm{~N}$ arasında değiştiği görülmektedir. Șekil 16'dan da görüleceği gibi, mıknatısların yüzey mıknatıslı yapıda olduğu ve statorunda M43_24G sac malzemesinin kullanıldığı tasarımlarda kuvvet değerleri, tüm eksenlerdeki hareket yönleri için birbirine yakın değerlerde bulunmuştur. En yüksek kuvvet değeri ise motorun yüzey mıknatıslı yapıda olduğu, NdFe35 mıknatıs malzemesi ve M43_24G sac malzemesinin kullanıldığı modelde elde edilmiştir.

\section{Sonuç}

$\mathrm{Bu}$ çalışmada küresel motorun farklı mıknatıs malzemeleri, farklı mıknatıs yapıları ve farklı stator-rotor yapıları için ayrı ayrı motor modelleri oluşturulmuş ve her bir modelin elektromanyetik analizleri yapılmıştır. Mıknatıs türleri olarak NdFe30, $\mathrm{NdFe} 35$ ve SmCo28 mıknatısları ve mıknatısların rotorda yerleşimleri olarak da gömülü düz, gömülü V-tipi ve yüzey mıknatıs yerleşimleri ele alınmıştır. Stator ve rotor yapıları için de steel_1008, M43_24G ve JFE_Steel_50JNE300 laminasyon malzemeleri kullanılmıştır. Her oluşturulan model için, $\alpha=45^{\circ}$ alınarak elektromanyetik analizler yapılmış, manyetik akı yoğunluğu dağılımları, kuvvet değerleri ve moment değerleri elde edilmiştir.

Yapılan elektromanyetik analizlerden elde edilen manyetik akı yoğunluğu dağılım grafiklerine göre, NdFe35 mıknatıs malzemesi için manyetik akı yoğunluğu 1.09 Tesla, NdFe30 mıknatıs malzemesi için 1.04 Tesla ve SmCo28 mıknatıs malzemesi için de 0.97 Tesla olarak elde edilmiştir. Yine akı yoğunluğu değerleri incelendiğinde, statorda manyetik doyum probleminin olmadığı gözlemlenmiştir. Ayrıca manyetik özellikleri farklı bu 3 mıknatısın, manyetik akı yoğunluğu farklılıklarının kuvvet değerlerine de yansıdığı ve akı yoğunluğundaki artışın, motorun eksenel kuvvet değerlerinde de artışa yol açtı̆̆ görülmüştür. Mıknatısların rotordaki yerleşim farklılıklarına göre yapılan analiz sonuçlarına göre ise, yüzey mıknatıslı yapının daha düzgün bir manyetik akı dağılımı sağladığı görülmüştür. Bu modelde kaçak akı azaltılabilmiş ve diğer mıknatıs yapılarından farklı olarak, her eksende sabit kuvvet ve moment elde edilebilmiştir. Yine yüzey mıknatıslı yapıda tasarlanan 9 farklı model arasında, NdFe35 mıknatıs malzemesi ve M43_24G sacının kullanıldığı motor modelinde en iyi sonuçların alındığı ve diğer tasarımlara göre en iyi kuvvet değerlerinin elde edildiği görülmüştür. Ayrıca manyetik akı yoğunluğu dağılımı incelediğinde, manyetik doyum probleminin olmadığı görülmüştür. Bu modelde, küresel motorun pozitif $\mathrm{X}$ ve $\mathrm{Y}$ ile negatif $\mathrm{X}$ ve $\mathrm{Y}$ yönlerinde ortalama $44 \mathrm{~N}$ kuvvet değeri ve $0.65 \mathrm{mNm}$ moment değeri elde edilmiştir.

Bu motor tasarım çalışması ile farklı mıknatıs malzemelerin kullanımının, küresel motorun manyetik akı yoğunluğu dağılımlarında değişimlere sebep olduğu, ayrıca küresel motorlarda moment, kuvvet ve eksenel hareket kabiliyetlerinin iyileştirilmesi için gereken değerlerin, bu analizlerle elde edilebileceği görülmüştür. Yine analiz çalışmalarından, küresel motorun stator kutuplarında kullanılan sargıların sarım sayısı ve iletken telin çapının optimize edilerek, moment değerinin artırılabileceği de görülmüsstür. Tasarım sonuçları irdelenerek yapılacak iyileştirme çalışmaları ile motorun ağılı̆̆̆ veya boyutu daha uygun hale getirilerek, tasarımında kullanılan malzemeler azaltılabilir ve böylece üretim maliyetinin de azaltılması sağlanabilir. Yine stator geometrisinde oluk sayısı ve rotorun mıknatıs sayısı optimize edilerek, eksenel hareketler sonucunda oluşacak kuvvet ve moment değerlerinin arttırılması sağlanabilir.

Küresel motorun bu farklı tasarım çalışmalarından görülmüştür ki, motor tasarımları farklı endüstriyel uygulama alanlarında kullanılacak şekilde optimize edilerek, istenen çalışma performansları elde edilebilmektedir. Mesela bu çalışma geliştirilip, küresel motorun stator yapısı üç katlı blok yapıdan oluşturulduğunda, stator için kullanılacak malzeme miktarı artmasına rağmen, oluşturulan stator orta bloğuyla küresel motorun hareketinin sabit kalması sağlanabilir.

\section{Kaynakça}

Ahmadi S., Moghani, J.S. and Mirsalim, M., "Simulation and Analysis of a Novel PM Spherical 3-DOF Actuator with E-Shaped Stator and Blade-Shaped Rotor Structure”, 2018 9th Annual Power Electronics, Drives Systems and Technologies Conference (PEDSTC), (2018).

ANSYS Maxwell Online Help, ANSYS Electronics 2020R1, ANSYS Inc. , (2020).

ANSYS Maxwell 2020R1, ANSYS, Inc., (2020).

Cho, S., Lim, J.S., Oh, Y.J., Jeong, G., Kang, D.W. and Lee, J., "A Study on Output Characteristics of the Spherical Multi-DOF Motor According to the Number of Phases and Pole Pitch Angles", IEEE TRANSACTIONS ON MAGNETICS, VOL. 54, NO. 11, NOVEMBER 2018, (2018).

El-Khalafawy, K. and El-Amary, N.H., "Spherical Actuator Design and Operation Based on Magnetic Profile", 2017 IEEE PES AsiaPacific Power and Energy Engineering Conference (APPEEC), (2017).

Laithwaite, E., "Design of spherical motors", Electrical Times, (9), 921-925, (1960).

Li, B., Li, Z., and Li, G., "Magnetic Field Model for Permanent Magnet Spherical Motor With Double Polyhedron Structure", IEEE TRANSACTIONS ON MAGNETICS, VOL. 53, NO. 12, DECEMBER 2017, (2017).

Li, H. and Li, T., "End-Effect Magnetic Field Analysis of the Halbach Array Permanent Magnet Spherical Motor", IEEE TRANSACTIONS ON MAGNETICS, VOL. 54, NO. 4, APRIL 2018, (2018).

Li, X., Bai, S., Chen, W. and Liu, J., "Torque Modelling and Current Optimization of a Spherical Actuator Built as an Electro-magnets Driven Spherical Parallel Manipulator", 2017 IEEE 8th International Conference on CIS \& RAM, Ningbo, China, (2017).

Li, Z., Chen, Q., Yue, F. and Zhang, Y., "Modal Analysis of Electromagnetic Resonance for Multi-degree-of-freedom Spherical Motor", 201821 st International Conference on Electrical Machines and Systems (ICEMS) October 7-10, 2018 Jeju, Korea, (2018).

Li, Z., Chen, Q. and Wang, Q., "Analysis of Multi-Physics Coupling Field of Multi-Degree-of-Freedom Permanent Magnet Spherical Motor”, IEEE TRANSACTIONS ON MAGNETICS, VOL. 55, NO. 6, JUNE 2019, (2019).

e-ISSN: $2148-2683$ 
Öner, Y., “Sabit Mıknatıslı Küresel Motorun Bilgisayar Destekli Üç Boyutlu Manyetik Analizi, Tasarımı Ve Uygulaması”, Doktora Tezi, Gazi Üniversitesi Fen Bilimleri Enstitüsü, Ankara, (2004).

Rong, Y., Wang, Q., Lu, S., Li, G., Lu, Y. and Xu, J., "Improving attitude detection performance for spherical motors using a MEMS inertial measurement sensor", IET Electr. Power Appl., 2019, Vol. 13 Iss. 2, pp. 198-205 @ The Institution of Engineering and Technology 2018, (2018).

Takahara, T., Hirata, K., Niguchi, N., Nishiura, Y. and Sakaidani, Y., "Experimental Evaluation of the Static Characteristics of MultiDegree-of-Freedom Spherical Actuators", IEEE TRANSACTIONS ON MAGNETICS, VOL. 53, NO. 11, NOVEMBER 2017, (2017).

Yan, L., Duan, Z., Zhang, Q., Qiao, H. and Gerada, C., "Development and Structure of Multi-DOF Spherical Induction Motor", 2018 13th IEEE Conference on Industrial Electronics and Applications (ICIEA)), (2018).

Zhou, F., Li, G., Zhou, R., Ju, L., Ma, G. and Cao, X., "Structural parameters optimization of permanent magnet spherical motor based on BP neural network model", 2017 12th IEEE Conference on Industrial Electronics and Applications (ICIEA), (2017).

Williams, F., Laithwaite, E. And Piggot, L., "Brushless variable speed induction motor", IEEE Proceedings, 2097U, 102-118, (1956).

Williams, F., Laithwaite, E. and Eastham, G.F., "Development of design of spherical induction motor”, IEEE Proceedings, 3036U, 471484, (1959). 